\section{Safety and efficacy of the BNT162b mRNA COVID-19 vaccine in patients with chronic lymphocytic leukemia}

\author{
Ohad Benjamini, ${ }^{1,2}$ Lior Rokach, ${ }^{3}$ Gilad Itchaki, ${ }^{4}$ Andrei Braester, ${ }^{5}$ Lev Shvidel, ${ }^{6}$ \\ Neta Goldschmidt, ${ }^{7}$ Shirley Shapira, ${ }^{8}$ Najib Dally, ${ }^{9}$ Abraham Avigdor, ${ }^{1,2}$ Galia \\ Rahav ${ }^{10,2}$ Yaniv Lustig, ${ }^{11}$ Shirley Shapiro Ben David, ${ }^{8}$ Riva Fineman, ${ }^{12}$ Alona \\ Paz, ${ }^{13,14}$ Osnat Bairey, ${ }^{4}$ Aaron Polliack, ${ }^{7}$ Ilana Levy ${ }^{15}$ and Tamar Tadmor ${ }^{14,15}$ on \\ behalf of the Israeli CLL study group (ICLLSG)
}

${ }^{1}$ Hematology Division, Chaim Sheba Medical Center, Tel-Hashomer, ${ }^{2}$ Sackler Faculty of Medicine, Tel-Aviv University, Tel-Aviv; ${ }^{3}$ Department of Software and Information Systems Engineering, Ben-Gurion University of the Negev, Beer-Sheva; ${ }^{4}$ Institute of Hematology, Davidoff Cancer Center, Rabin Medical Center, Petah Tikva; ${ }^{5}$ Department of Hematology, Galilee Medical Center, Nahariya; ${ }^{6} \mathrm{Hematology}$ Institute, Kaplan Medical Center, Rehovot; ${ }^{7}$ Hematology, Hadassah Medical Center, Jerusalem; ${ }^{8}$ Health Division, Maccabi Healthcare Services, Tel Aviv; 'Division of Hematology, Ziv Medical Center, Safed; ${ }^{10}$ The Infectious Disease Unit, Sheba Medical Center, Tel-Hashomer; ${ }^{11}$ Central Virology Laboratory, Ministry of Health and Sheba Medical Center, Tel-Hashomer; ${ }^{12}$ Department of Hematology and BMT, Rambam Health Care Campus, Haifa; ${ }^{13}$ Infectious Disease Unit, Bnai Zion Medical Center, Haifa; ${ }^{14}$ The Ruth and Bruce Rappaport Faculty of Medicine, Technion, Haifa and ${ }^{15} \mathrm{Hematology}$ Unit, Bnai Zion Medical Center, Haifa, Israel.

\section{ABSTRACT}

P atients with chronic lymphocytic leukemia (CLL) have a suboptimal humoral response to vaccination. Recently, BNT162b2, an mRNA COVID-19 vaccine with a high efficacy of $95 \%$ in immunocompetent individuals, was introduced. We investigated the safety and efficacy of the BNT162b2 mRNA COVID-19 vaccine in patients with CLL from nine medical centers in Israel, Overall 400 patients were included, of whom 373 were found to be eligible for the analysis of antibody response. The vaccine appeared to be safe and only grade 1-2 adverse events were seen in $50 \%$ of the patients. Following the second dose, an antibody response was detected in $43 \%$ of the cohort. Among these CLL patients, $61 \%$ of the treatment-naive patients responded to the vaccine, while responses developed in only $18 \%$ of those with ongoing disease, $37 \%$ of those previously treated with a BTK inhibitor and $5 \%$ of those recently given an anti-CD20 antibody. Among patients treated with BCL2 as monotherapy or in combination with anti-CD20, $62 \%$ and $14 \%$, respectively, developed an immune response. There was a high concordance between neutralizing antibodies and positive serological response to spike protein. Based on our findings we developed a simple seven-factor score including timing of any treatment with anti-CD20, age, treatment status, and IgG, IgA, IgM and hemoglobin levels. The sum of all the above parameters can serve as a possible estimate to predict whether a given CLL patient will develop sufficient antibodies. In conclusion, the BNT162b2 mRNA COVID-19 vaccine was found to be safe in patients with CLL, but its efficacy is limited, particularly in treated patients.

\section{Introduction}

The coronavirus disease 2019 (COVID-19) pandemic has become the main healthcare issue worldwide since its appearance at the end of 2019, with the disease affecting millions of people globally. ${ }^{1}$ International efforts generated a vaccine against the causative virus, severe acute respiratory syndrome coronavirus-2 (SARS-
Haematologica 2022

Volume 107(3):625-634

\section{Correspondence:}

TAMAR TADMOR

Tamar.tadmor@b-zion.org.il

Received: May 11, 2021.

Accepted: July 8, 2021.

Pre-published: July 29, 2021.

https://doi.org/10.3324/haematol.2021.279196

(C)2022 Ferrata Storti Foundation

Material published in Haematologica is covered by copyright. All rights are reserved to the Ferrata Storti Foundation. Use of published material is allowed under the following terms and conditions:

https://creativecommons.org/licenses/by-nc/4.0/legalcode. Copies of published material are allowed for personal or internal use. Sharing published material for non-commercial purposes is subject to the following conditions:

https://creativecommons.org/licenses/by-nc/4.0/legalcode, sect. 3. Reproducing and sharing published material for com mercial purposes is not allowed without permission in writing from the publisher. 
CoV-2), which was both safe and highly effective. In December 2020, results of a clinical trial using the BNT162b2 mRNA COVID-19 vaccine in a large cohort of people ( $\geq 16$ years old) demonstrated a $95 \%$ efficacy in preventing symptomatic infection. ${ }^{2}$ This study prompted an emergency use authorization from the Food and Drug Administration. ${ }^{3}$ In a real-world setting, nationwide vaccination data from Israel documented high efficacy of the vaccine even in patients with multiple comorbidities. ${ }^{4}$ However, the trial excluded immunosuppressed patients, as their immune response to vaccination is usually blunted.

Chronic lymphocytic leukemia (CLL) is associated with varying degrees of immune deficiency due to the primary disease or to the therapy administered. These include functional defects of B- and T-lymphocytes, natural killer cells, neutrophils and macrophages, ${ }^{5}$ as well as hypogammaglobulinemia, which is evident in treatment-naive patients and develops even more frequently following therapy for CLL. ${ }^{5,6}$

Large, retrospective studies from both Europe $e^{7,8}$ and the $\mathrm{USA}^{9}$ have already shown that patients with CLL have an increased rate of COVID-19 infection, a higher hospitalization rate and a greater risk of dying from the virus irrespective of disease stage or prior treatment status. The role of vaccination in these patients is therefore of major importance. However, several studies have already shown that patients with CLL mount limited responses to other more frequently used vaccines, such as those for influen$\mathrm{za}^{10}{ }^{10}$ pneumococcal infection ${ }^{11}$ and varicella zoster. ${ }^{12}$ Furthermore, only limited data are available on the response to vaccines in the era of novel biological agents now used to treat CLL, such as BTK and BCL2 inhibitors in combination with anti-CD20 antibodies. ${ }^{13-15}$ A previous publication described a reduced serological response rate to the BNT162b2 vaccine in patients with CLL, compared to that in healthy controls, particularly during therapy. ${ }^{16}$

The aim of the study we report here was to investigate the safety and efficacy of the BNT162b2 mRNA COVID19 vaccine in patients with CLL and the effect of therapy on the serological response to the vaccine, given in nine medical centers in different parts of Israel.

\section{Methods}

\section{Patients}

This was a prospective, interventional, multicenter study that was performed on behalf of the Israeli CLL study group. The data retrieved from nine centers in Israel provided information on a total of 400 CLL patients who had been vaccinated with the BNT162b2 mRNA COVID-19 vaccine.

The diagnosis of CLL was established according to International Workshop CLL criteria. ${ }^{5}$ Data were collected from medical records after approval from all of the individual institutes' ethics committees and all patients who participated gave written informed consent. The study was registered at ClinicalTrials.gov NCT04862806 The referring physicians collected demographic and clinical data from the patients' medical records, including patients' characteristics (gender, age, Binet stage, medical history including Cumulative Illness Rating Scale [CIRS] score), previous treatments (number and type), and biological features of the CLL (serum IgG, IgA, IgM levels, IGHV mutation status, fluorescence in situ hybridization [FISH] cytogenetic profile, and TP53 mutation) whenever available.

\section{Vaccination and immune response assessment}

All patients received two $30 \mu \mathrm{g}$ doses of BNT162b2 vaccine (Pfizer), administered intramuscularly 3 weeks apart. Blood samples for immune response evaluation to the vaccine were assessed 2-3 weeks (median, 19 days) after the second dose using anti-spike $(\mathrm{S})$ antibody tests. Anti-spike antibody tests were performed in each hospital using one of three available commercial kits: The Liaison SARS-CoV-2 S1/S2 IgG (Diasorin, Saluggia, Italy), with a positive cutoff of $>15 \mathrm{U} / \mathrm{mL}$; the Architect AdviseDx SARS-CoV-2 IgG II (Abbot, Lake Forest, IL, USA), with a positive cutoff of $>50$ $\mathrm{U} / \mathrm{mL}$. and an enzyme-linked immunosorbent assay (ELISA) that detects IgG antibodies against the receptorbinding domain (RBD) of SARS-CoV-2 (positive value $>1.1$; range $1.1-10){ }^{17,18}$

A surrogate viral assay was used to test antiviral humoral response based on a highly infectious recombinant vesicular stomatitis virus (VSV) bearing the SARS-CoV-2 spike glycoprotein $\mathrm{S}$. This recombinant virus, rVSV-SARS-CoV-2 or SARS-CoV-2 pseudo-virus (psSARS-2), closely resembles SARS-CoV-2 in its entry-related properties. The psSARS-2 neutralization assay was performed using a propagationcompetent VSV-spike similar to the one previously published, which was kindly provided by Gert Zimmer (University of Bern, Switzerland). ${ }^{19}$

\section{Safety}

On the day of the serological test, patients were asked to report any adverse events and filled in a questionnaire related to the development of local and systemic adverse events. Patients reported in free text if they had had any adverse events after either vaccination and answered a multiplechoice questionnaire with a scale from zero to five, where zero indicated the lack of any adverse events.

\section{Statistical analysis}

The characteristics of IgG responders and IgG nonresponders were compared using the Mann-Whitney test for continuous variables, while the Wald $\chi^{2}$ test was used for the comparison of categorical variables. Some continuous variables were also tested as categorical variables using the thresholds indicated in the tables and text. A $P$ value $<0.05$ was considered statistically significant.

For the predictive model, multivariate logistic regression was used to predict the response to the vaccine and determine which variables were independently associated with the response. Least absolute shrinkage and selection operator (LASSO) regularization was used to avoid over-fitting and obtain a simpler model which consists of only the informative variables while disregarding the remaining variables. We compared the predictive performance of the LASSO logistic regression model with the simple sevenfactor score. We applied ten repeats of stratified 10-fold cross-validation to estimate the various predictive performance metrics (area under the curve, accuracy, specificity and sensitivity) and their variance. This procedure helps to avoid over-estimation of the predictive performance of LASSO logistic regression.

LASSO estimates regression coefficients by maximizing the log-likelihood function, like any other logistic regression, but by adding a constraint that the sum of the absolute values of the regression coefficients is less than or equal to a positive constant. ${ }^{20,21}$ Thus, LASSO prefers a parsimonious model, penalizing models with too many variables. In particular, if there is a subset of highly correlated 
variables (e.g., white blood cell count and absolute lymphocyte count), then LASSO tends to select one variable from this set and ignore the others. This helps to avoid selection bias and poor predictive performance in relatively small datasets ${ }^{17}$ and is therefore very useful in medical applications. ${ }^{20,21}$

\section{Results}

A total of 400 patients with CLL were recruited into the trial from nine medical institutes in Israel between December 2020 and February 2021. Our vaccine response analysis is based on the data obtained from 373 patients after excluding the following patients: 14 patients whose serology tests were taken too early $(<12$ days after the second dose), one patient who had received the Moderna vaccine, nine patients whose antibody tests were not collected and three patients who were infected by SARS-CoV-2 after vaccination. Blood samples were analyzed 2-3 weeks (median 19 days; range, 12-53) after the patients had received the second dose of the vaccine.

The median age of the entire cohort was 70 years old (range, 40-89), and 222 (58.9\%) were male. The median time since diagnosis of CLL was 83 months for the whole cohort, and 66 months and 97 months in patients with or without a serological response, respectively. (Table 1)

\section{Side effects of the vaccine}

Figure 1 and Online Supplementary Table S1 provide details of adverse events following administration of the BNT162b2 mRNA COVID-19 vaccine to patients with CLL. Patients were asked about the development of fever, rash, pain at the site of injection or generalized muscle pain. Of the 331 patients who answered the questionnaire, 180 $(54.4 \%)$ reported no side effects following the two doses of the vaccine. All side effects that were reported were either grade $1(41.7 \%)$ and/or grade $2(4 \%)$. The most frequent was local pain at the site of injection, which was reported by $32.3 \%$ of the cohort. The most frequent grade 2 side effects were pain and fever, reported by $4.3 \%$ and $3.6 \%$ of the patients, respectively. Other side effects of interest noted by the investigators included one case of facial numbness lasting for $12 \mathrm{~h}$, which resolved without sequelae. In the open question of the questionnaire 12 patients reported fatigue, and eight complained of headache. Two patients developed autoimmune hemolytic anemia, which was detected on the day of the serology test at 18 and 35 days after the second vaccine with hemoglobin levels of 5.6 $\mathrm{mg} / \mathrm{dL}$ and $4.71 \mathrm{mg} / \mathrm{dL}$, respectively. Both patients were in

Table 1. Clinical and demographic parameters and efficacy of the BNT162b2 mRNA COVID-19 vaccine in patients with chronic lymphocytic leukemia.

\begin{tabular}{|c|c|c|c|c|c|}
\hline \multirow[t]{2}{*}{ Variable } & \multicolumn{2}{|c|}{ Serological response } & \multirow{2}{*}{$\begin{array}{c}\text { Total } \\
n=373\end{array}$} & \multirow{2}{*}{$\begin{array}{l}\text { Oddis ratio } \\
(95 \% \text { CI) }\end{array}$} & \multirow[t]{2}{*}{ P-value } \\
\hline & $\begin{array}{c}\text { Positive } \\
n=160(43 \%)\end{array}$ & $\begin{array}{l}\text { Negative } \\
n=213(57 \%)\end{array}$ & & & \\
\hline $\begin{array}{l}\text { Median age in years (range) } \\
\leq 70 \text { years, } \mathrm{n}(\%) \\
>70 \text { years, } \mathrm{n}(\%)\end{array}$ & $\begin{array}{c}69(40-88) \\
99(48 \%) \\
61(37 \%)\end{array}$ & $\begin{array}{l}71(44-89) \\
109(52 \%) \\
104(63 \%)\end{array}$ & $\begin{array}{l}208 \\
165\end{array}$ & $\begin{array}{c}1 \text { (ref) } \\
0.65(0.43-0.98)\end{array}$ & $\begin{array}{c}<0.001 \\
0.04\end{array}$ \\
\hline $\begin{array}{l}\text { Sex, } n(\%) \\
\text { Female } \\
\text { Male }\end{array}$ & $\begin{array}{l}65(43 \%) \\
95(43 \%)\end{array}$ & $\begin{array}{l}86(57 \%) \\
127(57 \%)\end{array}$ & $\begin{array}{l}151 \\
222\end{array}$ & $\begin{array}{c}1 \text { (ref) } \\
0.99(0.65-1.5)\end{array}$ & 0.96 \\
\hline $\begin{array}{l}\text { Median time since CLL diagnosis } \\
\text { in months (range) }\end{array}$ & $66(1-362)$ & $97(3-341)$ & & & $<10^{4}$ \\
\hline $\begin{array}{l}\text { Binet Stage, }{ }^{*} \text { n (\%) } \\
\text { A } \\
\text { B } \\
\text { C }\end{array}$ & $\begin{array}{l}75(66 \%) \\
13(45 \%) \\
4(44 \%)\end{array}$ & $\begin{array}{l}38(34 \%) \\
16(55 \%) \\
5(56 \%)\end{array}$ & $\begin{array}{c}113 \\
29 \\
9\end{array}$ & $\begin{array}{c}1 \text { (ref) } \\
0.41(0.18-1.1) \\
0.41(0.1-1.6)\end{array}$ & $\begin{array}{l}0.06 \\
0.19\end{array}$ \\
\hline $\begin{array}{l}\text { Diabetes mellitus, n (\%) } \\
\text { No } \\
\text { Yes }\end{array}$ & $\begin{array}{l}131(44 \%) \\
29(38 \%)\end{array}$ & $\begin{array}{l}165(56 \%) \\
48(62 \%)\end{array}$ & $\begin{array}{c}296 \\
77\end{array}$ & $\begin{array}{c}1 \text { (ref) } \\
0.761(0.45-1.27)\end{array}$ & 0.3 \\
\hline $\begin{array}{l}\text { Ischemic heart disease, n (\%) } \\
\text { No } \\
\text { Yes }\end{array}$ & $\begin{array}{l}140(44 \%) \\
20(37 \%)\end{array}$ & $\begin{array}{l}179(56 \%) \\
34(63 \%)\end{array}$ & $\begin{array}{c}319 \\
54\end{array}$ & $\begin{array}{c}1(\mathrm{ref}) \\
0.7521(0.41-1.36)\end{array}$ & 0.35 \\
\hline $\begin{array}{l}\text { Hypertension, n (\%) } \\
\text { No } \\
\text { Yes }\end{array}$ & $\begin{array}{l}105(44 \%) \\
55(41 \%)\end{array}$ & $\begin{array}{l}134(56 \%) \\
79(59 \%)\end{array}$ & $\begin{array}{l}239 \\
134\end{array}$ & $\begin{array}{c}1 \text { (ref) } \\
0.8885(0.58-1.36)\end{array}$ & 0.59 \\
\hline $\begin{array}{l}\text { R-CIRS, median (range) } \\
<6, \mathrm{n}(\%) \\
\geq 6, \mathrm{n}(\%)\end{array}$ & $\begin{array}{l}4(0-11) \\
84(48 \%) \\
54(36 \%)\end{array}$ & $\begin{array}{c}5(0-19) \\
91(52 \%) \\
98(64 \%)\end{array}$ & $\begin{array}{l}175 \\
152\end{array}$ & $\begin{array}{c}1 \text { (ref) } \\
0.5969(0.38-0.93)\end{array}$ & $\begin{array}{l}0.004 \\
0.02\end{array}$ \\
\hline $\begin{array}{l}\text { Lymphadenopathy, n (\%) } \\
\text { No } \\
\text { Yes }\end{array}$ & $\begin{array}{l}41(41 \%) \\
32(38 \%)\end{array}$ & $\begin{array}{l}60(59 \%) \\
53(62 \%)\end{array}$ & $\begin{array}{l}101 \\
85\end{array}$ & $\begin{array}{c}1 \text { (ref) } \\
0.8836(0.49-1.6)\end{array}$ & 0.68 \\
\hline $\begin{array}{l}\text { Splenomegaly, n (\%) } \\
\text { No } \\
\text { Yes }\end{array}$ & $\begin{array}{l}47(39 \%) \\
11(31 \%)\end{array}$ & $\begin{array}{l}73(61 \%) \\
24(69 \%)\end{array}$ & $\begin{array}{c}120 \\
35\end{array}$ & $\begin{array}{c}1 \text { (ref) } \\
0.7119(0.32-1.59)\end{array}$ & 0.41 \\
\hline
\end{tabular}




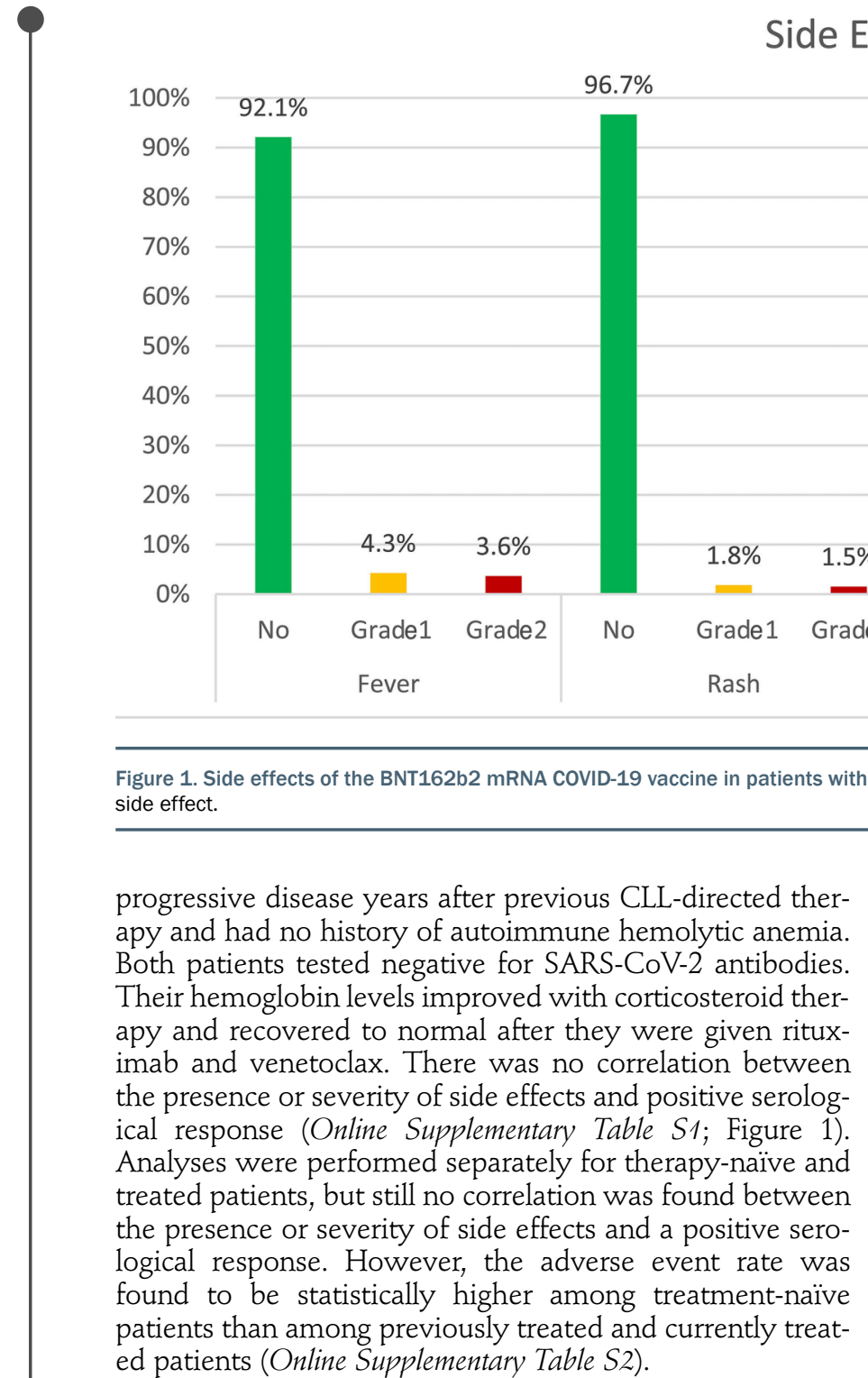

\section{Vaccine efficacy}

A positive antibody response to the vaccine was evident in only $160(43 \%)$ of all the patients with CLL.

In univariate analysis, the following variables were found to be highly statistically significantly $(P<0.001)$ associated with the lack of development of an immune response to the vaccine: low $\operatorname{IgG}(<700 \mathrm{mg} / \mathrm{dL})$, low $\operatorname{IgM}(<40 \mathrm{mg} / \mathrm{dL})$, low IgA $(<80 \mathrm{mg} / \mathrm{dL})$, platelet count $<150 \times 10^{9} / \mathrm{L}$, hemoglobin below normal value, number of prior therapies for CLL, recent anti-CD20 antibody treatment, and currently being treated with BTK inhibitors or BCL2 inhibitors. A few other variables were found to be statistically significantly $(P<0.05)$ associated, including CIRS score $>6$, age $>70$ and trisomy 12. There was no significant difference with regard to gender, comorbidities, FISH results except trisomy 12 or IGHV mutational status. Additional information is available in Table 2.

Multivariate logistic regression was used to predict response to vaccination and determine which variables were independently associated with the response (Table 4). LASSO regularization was used to avoid over-fitting and obtain a simpler model, which retained only the informative variables while disregarding the remaining variables.
The following independent variables were found to be statistically significant: age $>70$ years, recent treatment with anti-CD20 antibody, ongoing treatment with ibrutinib, IgG $<700 \mathrm{mg} / \mathrm{dL}$ and $\operatorname{IgM}<40 \mathrm{mg} / \mathrm{dL}$.

\section{Neutralizing antibodies}

Samples from 45 patients at Sheba Medical Center were also tested for the production of neutralizing antibodies. A pseudo typed virus system based on VSV was developed for the detection of neutralizing antibodies, instead of using infectious and viable viruses, due to safety concerns. Neutralizing antibodies prevent the pseudovirus from entering the host cells. As shown in Figure 2, the amount of neutralizing antibodies (log transformed) is correlated linearly with anti-COVID-19 RBDIgG titer $(\mathrm{r}=0.83$ and $P<0.001)$. Moreover, as demonstrated in the correlation matrix, 25 of 26 patients with positive IgG were also positive for neutralizing antibodies (the $26^{\text {th }}$ patient was not tested for neutralizing antibodies). Similarly, 14 of 17 patients who were negative for anti-COVID-19 IgG were also negative for neutralizing antibodies (the neutralizing antibodies of the remaining 3 patients were not determined). The Choen $\mathrm{\kappa}$ agreement between IgG and neutralizing antibodies was $\kappa=0.75 \pm 0.08(P<0.001)$ which is indicative of high concordance between the two tests.

\section{Vaccine efficacy according to treatment status and type of anti-leukemia therapy given}

One hundred fifty eight $(42.3 \%)$ patients were treatmentnaive and of these 97 (61\%) developed an IgG response to the vaccine. The immune response was better in treatmentnaïve patients than in previously treated patients and was graded according to CLL disease status (vaccine response better in therapy-naïve patients $>$ complete response $>$ partial response $>$ progressive disease) (Figure 3A)

In the treated cohort: an inverse correlation was found between number of lines of prior anti-CLL therapy and the development of a serological response. (Table 2). 


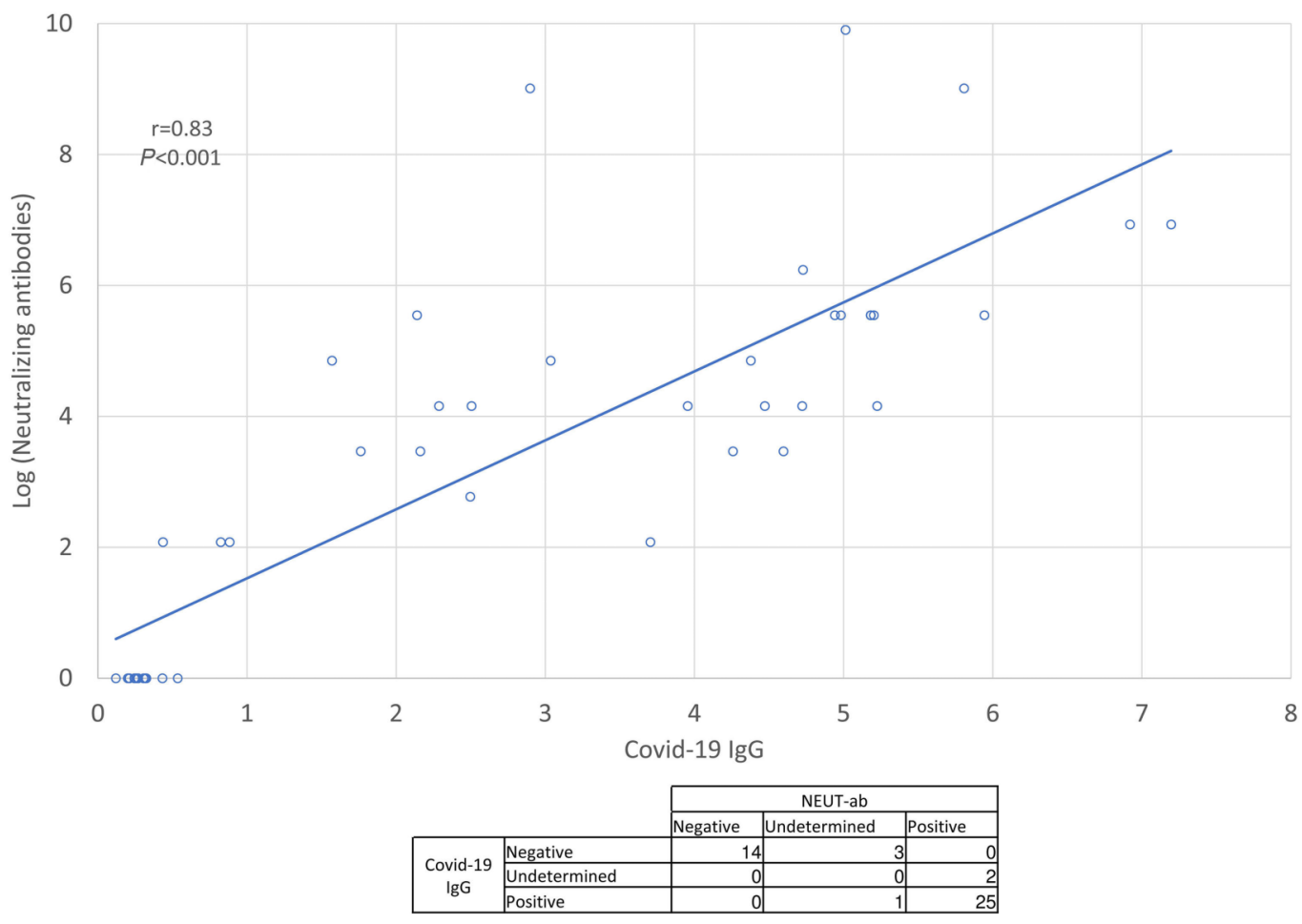

Figure 2. Correlation between neutralizing antibodies and COVID-19 IgG titer. NEUT Ab: neutralizing antibodies.

Of the $143(38 \%)$ patients previously treated with antiCD20 antibodies, only $38(27 \%)$ responded to the vaccine and there was a significantly lower antibody response rate of only $5 \%$ in patients treated with anti-CD20 antibodies within the year of vaccination compared to $35 \%$ when the time from anti-CD20 therapy was more than 1 year (Table 3)

Analysis of the serological response in 106 patients treated with BTK inhibitors revealed positive serological responses in $23 \%$ of the patients. There was a statistical difference between the response rate in patients receiving ongoing BTK inhibitor therapy $(18 \%)$ and that in previously treated patients (37\%). However, there was no statistical difference depending on whether the BTK inhibitor was given within 2 years or more than 2 years from the time of vaccination or depending on whether it was given as firstline therapy or in relapsed disease (Table 2, Figure 3B).

Sixty-two patients were treated with BCL2 inhibitors and of them $24 \%$ developed a positive serological response. Among those in whom BCL2 inhibition was combined with anti-CD20 antibodies only $14 \%$ developed a positive serological response. There was no statistical difference depending on whether patients received BCL2 inhibitor therapy within or more than a year before vaccination, or depending on whether the BCL2 inhibitor was given as first-line therapy or at relapse; however when the BCL3 inhibitor was combined with antiCD20 antibodies, vaccine response rates were lower.

Therapy with prophylactic intravenous immunoglobulins also correlated with vaccine response. Additional information is available in Table 2 and Figure 3B, C.

\section{The effect of the vaccine on IgG levels}

We compared IgG levels before and after vaccination. More specifically we compared IgG levels that were meas- ured up to 150 days before the first dose of vaccine (when applicable) with the IgG levels of the corresponding patients at the serology test of this study and found that they were similar (mean levels: $768.89 \mathrm{mg} / \mathrm{dL}$ vs. 755.74 $\mathrm{mg} / \mathrm{dL}$, respectively).

\section{A simple score to predict response to vaccine in individual patients with chronic lymphocytic leukemia}

In addition to the multivariate logistic regression model, we generated a simple score based on seven factors (Figure 4): (i) anti-CD20 treatment in the 12 months preceding vaccination (no: +30 ; yes: 0); (ii) treatment status (treatmentnaïve: +10 ; previous or ongoing treatment: 0$)$, (iii) age $(<70$ years. +10 ; $\geq 70$ years: 0 ); (iv) IgM level $(\geq 40 \mathrm{mg} / \mathrm{dL}:+10$; $<40 \mathrm{mg} / \mathrm{dL}$ : 0); (v) IgA level ( $\geq 80 \mathrm{mg} / \mathrm{dL}:+10 ;<80 \mathrm{mg} / \mathrm{dL}: 0$ ), (vi) IgG level ( $\geq 700 \mathrm{mg} / \mathrm{dL}:+10$; $<700 \mathrm{mg} / \mathrm{dL}: 0$ ), and (vii) hemoglobin concentration (normal [i.e., $\geq 13.5 \mathrm{~g} / \mathrm{dL}$ for males and $\geq 12 \mathrm{~g} / \mathrm{dL}$ for females]: +10; low: 0). All this information is readily available from the clinical history and a routine and affordable blood test.

The sum of all the above parameters in the scoring model can be used to estimate the probability of a given CLL patient developing sufficient antibodies after vaccination. For example, a 65 -year-old $(+10)$, pretreated $(+0)$ patient but not with anti-CD20 in the preceding 12 months $(+30)$ with normal $\operatorname{IgA}(+10), \operatorname{IgG}(+10)$ and hemoglobin $(+10)$ levels but abnormal IgM $(+0)$ has a score of 70 . i.e., a $70 \%$ probability of developing antibodies above the cutoff. Note that according to the model, the maximum score that can be obtained is 90 and not 100 , highlighting the fact that even patients with the most favorable indicators are still at risk of not developing a response to vaccination. In the case that the value of a certain factor is missing, we redistribute its score among the other known factors according to their weights. 
Table 2. Response to the BNT162b2 mRNA COVID-19 vaccine based on type of prior therapy given for chronic lymphocytic leukemia.

\begin{tabular}{|c|c|c|c|c|c|}
\hline \multirow[t]{2}{*}{ Variable } & \multicolumn{2}{|c|}{ Serological response } & \multirow{2}{*}{$\begin{array}{l}\text { Total } \\
n=373\end{array}$} & \multirow{2}{*}{$\begin{array}{l}\text { Odds ratio } \\
(95 \% \text { CI) }\end{array}$} & \multirow[b]{2}{*}{ P-value } \\
\hline & $\begin{array}{c}\text { Positive } \\
n=160(43 \%)\end{array}$ & $\begin{array}{l}\text { Negative } \\
n=213(57 \%)\end{array}$ & & & \\
\hline $\begin{array}{l}\text { Prior therapies, median (range) } \\
\text { Treatment- naive, n (\%) } \\
\text { One, n (\%) } \\
\text { Two or more, n (\%) }\end{array}$ & $\begin{array}{c}0(0-4) \\
97(61 \%) \\
35(29 \%) \\
28(29 \%)\end{array}$ & $\begin{array}{l}1(0-6) \\
61(39 \%) \\
85(71 \%) \\
67(71 \%)\end{array}$ & $\begin{array}{c}1 \\
158 \\
120 \\
95\end{array}$ & $\begin{array}{c}1 \text { (ref) } \\
0.26(0.16-0.43) \\
0.26(0.15-0.45)\end{array}$ & $\begin{array}{l}<10^{-5} \\
<10^{-3} \\
<10^{-5}\end{array}$ \\
\hline $\begin{array}{l}\text { Ongoing therapy } \\
\text { None, } \mathrm{n}(\%)\end{array}$ & $143(57 \%)$ & $110(43 \%)$ & 253 & 1 (ref) & \\
\hline $\begin{array}{l}\text { Previous antiCD20, n (\%) } \\
\text { No } \\
\text { Yes }\end{array}$ & $\begin{array}{l}98(50 \%) \\
38(27 \%)\end{array}$ & $\begin{array}{l}99(50 \%) \\
105(73 \%)\end{array}$ & $\begin{array}{l}197 \\
143\end{array}$ & $\begin{array}{c}1 \text { (ref) } \\
0.37(0.23-0.58)\end{array}$ & 0.0001 \\
\hline $\begin{array}{l}\text { Time since anti-CD20, months, } \\
\text { median (range) } \\
\geq 12 \text { months, } \mathrm{n}(\%) \\
<12 \text { months, } \mathrm{n}(\%)\end{array}$ & $\begin{array}{c}48(10-102) \\
32(35 \%) \\
2(5 \%)\end{array}$ & $\begin{array}{l}27(1-132) \\
60(65 \%) \\
37(95 \%)\end{array}$ & $\begin{array}{l}36 \\
92 \\
39\end{array}$ & $\begin{array}{c}1 \text { (ref) } \\
0.1(0.02-0.45)\end{array}$ & $\begin{array}{l}0.142 \\
0.0004\end{array}$ \\
\hline BTK inhibitor & $n=24(23 \%)$ & $n=82(77 \%)$ & $n=106$ & & \\
\hline $\begin{array}{l}\text { Ongoing BTK inhibitors, } \mathrm{n}(\%) \\
\text { BTK inhibitors in the past, } \mathrm{n}(\%)\end{array}$ & $\begin{array}{l}14(18 \%) \\
10(37 \%)\end{array}$ & $\begin{array}{l}65(82 \%) \\
17(63 \%)\end{array}$ & $\begin{array}{l}79 \\
27\end{array}$ & $\begin{array}{c}1 \text { (ref) } \\
2.73(1.03-7.21)\end{array}$ & 0.0384 \\
\hline $\begin{array}{l}\text { Treatment duration, } n(\%) \\
<2 \text { years } \\
\geq 2 \text { years }\end{array}$ & $\begin{array}{l}14(26 \%) \\
10(19 \%)\end{array}$ & $\begin{array}{l}40(74 \%) \\
42(81 \%)\end{array}$ & $\begin{array}{l}54 \\
52\end{array}$ & $\begin{array}{c}1 \text { (ref) } \\
0.68(0.27-1.71)\end{array}$ & 0.4103 \\
\hline $\begin{array}{l}\text { Line of treatment, } n(\%) \\
\text { First line } \\
\text { Second line or beyond }\end{array}$ & $\begin{array}{l}15(28 \%) \\
9(17 \%)\end{array}$ & $\begin{array}{l}38(72 \%) \\
44(83 \%)\end{array}$ & $\begin{array}{l}53 \\
53\end{array}$ & $\begin{array}{c}1 \text { (ref) } \\
0.5182(0.2-1.32)\end{array}$ & 0.1638 \\
\hline BCL2 inhibitor & $n=15(24 \%)$ & $n=47(76 \%)$ & $n=62$ & & \\
\hline $\begin{array}{l}\text { Ongoing, } \mathrm{n}(\%) \\
\text { In the past, } \mathrm{n}(\%)\end{array}$ & $\begin{array}{c}2(6 \%) \\
13(46 \%)\end{array}$ & $\begin{array}{l}32(94 \%) \\
15(54 \%)\end{array}$ & $\begin{array}{l}34 \\
28\end{array}$ & $\begin{array}{c}1 \text { (ref) } \\
13.87(2.77-69.38)\end{array}$ & 0.0002 \\
\hline $\begin{array}{l}\text { Treatment duration, } \mathrm{n}(\%) \\
\leq 1 \text { year } \\
>1 \text { year }\end{array}$ & $\begin{array}{l}8(19 \%) \\
7(35 \%)\end{array}$ & $\begin{array}{l}34(81 \%) \\
13(65 \%)\end{array}$ & $\begin{array}{l}42 \\
20\end{array}$ & $\begin{array}{c}1 \text { (ref) } \\
2.2885(0.69-7.59)\end{array}$ & 0.1703 \\
\hline $\begin{array}{l}\text { Line of treatment, } \mathrm{n}(\%) \\
\text { First line } \\
\text { Second line or beyond }\end{array}$ & $\begin{array}{l}8(24 \%) \\
7(25 \%)\end{array}$ & $\begin{array}{l}26(76 \%) \\
21(75 \%)\end{array}$ & $\begin{array}{l}34 \\
28\end{array}$ & $\begin{array}{c}1 \text { (ref) } \\
1.0833(0.34-3.48)\end{array}$ & 0.893 \\
\hline $\begin{array}{l}\text { +- anti CD20, n (\%) } \\
\text { Without antiCD20 } \\
\text { With anti-CD20 }\end{array}$ & $\begin{array}{l}8(62 \%) \\
7(14 \%)\end{array}$ & $\begin{array}{c}5(38 \%) \\
42(86 \%)\end{array}$ & $\begin{array}{l}13 \\
49\end{array}$ & $\begin{array}{c}1 \text { (ref) } \\
0.1042(0.03-0.41)\end{array}$ & 0.0004 \\
\hline $\begin{array}{l}\mathrm{IVIG}^{*}, \mathrm{n}(\%) \\
\text { No } \\
\text { Yes }\end{array}$ & $\begin{array}{l}145(46 \%) \\
15(28 \%)\end{array}$ & $\begin{array}{l}172(54 \%) \\
39(72 \%)\end{array}$ & $\begin{array}{c}317 \\
54 \\
\end{array}$ & $\begin{array}{c}1 \text { (ref) } \\
0.46(0.24-0.86)\end{array}$ & 0.0137 \\
\hline
\end{tabular}

${ }^{*}$ Given monthly. 95\% CI: 95\% confidence interval; IVIG: intravenous immunoglobulins.

Based on the proposed score, patients could be divided into three groups: low vaccine responsive $(<20)$, intermediate responsive (20-70) and high responsive (>70) with significantly different response rates: $6 \%, 35 \%$ and $75 \%$ respectively.

The proposed scoring model presented in Online Supplementary Figure $S 1$ was formed by adding two new constraints to the logistic regression model: (A) the sum of absolute logistic transformed coefficients is less than or equal to 100; and (B) each coefficient is multiples of 10. The solution of this constrained scoring model was obtained using IBM CPLEX Optimization Studio.

We compared the predictive performance of the LASSO logistic regression model with that of the simple seven-factor models and applied ten repeats of stratified 10-fold crossvalidation to estimate predictive performance and its variance (Online Supplementary Table S3). It can be seen that the proposed risk scoring model has almost the same predictive performance as the LASSO logistic regression model.

\section{Discussion}

This study investigated a large series of patients with CLL following vaccination with the BNT162b2 mRNA COVID19 vaccine in an attempt to better define the safety of the vaccine and the extent of the immune response to it in these cases. It was found that the adverse events in CLL patients were similar to those encountered in immunocompetent populations and were mainly of grade 1-2 severity. In terms of efficacy, the proportion of patients with CLL with an adequate response was lower (43\%) than that in the healthy population $(97.4 \%){ }^{2}$ Our results are in keeping with those of previous studies on other vaccines which had already shown the limited efficacy of vaccination in patients with CLL. ${ }^{10-15}$

In our study patients who were more likely to develop an adequate immune response were younger than 70 years old, had normal hemoglobin and immunoglobulin levels and had not previously received CLL-directed treatment. 
Table 3. Response to the BNT162b2 mRNA COVID-19 vaccine based on laboratory and genetic parameters.

\begin{tabular}{|c|c|c|c|c|c|}
\hline Variable & $\begin{array}{c}\text { Sero } \\
\text { Positive } \\
n=160(43 \%)\end{array}$ & $\begin{array}{l}\text { Negative } \\
n=213(57 \%)\end{array}$ & $\begin{array}{l}\text { Total } \\
n=373\end{array}$ & $\begin{array}{l}\text { Odds ratio } \\
\text { (95\% CI) }\end{array}$ & P-value \\
\hline $\begin{array}{l}\text { dell7p, n (\%) } \\
\text { No } \\
\text { Yes }\end{array}$ & $\begin{array}{c}75(33 \%) \\
9(30 \%)\end{array}$ & $\begin{array}{l}151(67 \%) \\
21(70 \%)\end{array}$ & $\begin{array}{c}226 \\
30\end{array}$ & $\begin{array}{c}1 \text { (ref) } \\
0.86(0.38-1.98)\end{array}$ & 0.727 \\
\hline $\begin{array}{l}\text { dell1q, n (\%) } \\
\text { No } \\
\text { Yes }\end{array}$ & $\begin{array}{l}70(33 \%) \\
14(32 \%)\end{array}$ & $\begin{array}{l}141(67 \%) \\
30(68 \%)\end{array}$ & $\begin{array}{c}211 \\
44\end{array}$ & $\begin{array}{c}1 \text { (ref) } \\
0.94(0.47-1.89)\end{array}$ & 0.8617 \\
\hline $\begin{array}{l}\text { dell3q, n (\%) } \\
\text { No } \\
\text { Yes }\end{array}$ & $\begin{array}{l}49(33 \%) \\
28(29 \%)\end{array}$ & $\begin{array}{l}99(67 \%) \\
67(71 \%)\end{array}$ & $\begin{array}{c}148 \\
95\end{array}$ & $\begin{array}{c}1 \text { (ref) } \\
0.84(0.48-1.48)\end{array}$ & 0.5524 \\
\hline $\begin{array}{l}\text { trisomy } 12, \mathrm{n}(\%) \\
\text { No } \\
\text { Yes }\end{array}$ & $\begin{array}{l}65(35 \%) \\
10(19 \%)\end{array}$ & $\begin{array}{l}123(65 \%) \\
42(81 \%)\end{array}$ & $\begin{array}{l}188 \\
52\end{array}$ & $\begin{array}{c}1 \text { (ref) } \\
0.45(0.21-0.96)\end{array}$ & 0.0346 \\
\hline $\begin{array}{l}\text { TP53 mutation, n (\%) } \\
\text { No } \\
\text { Yes }\end{array}$ & $\begin{array}{l}28(29 \%) \\
3(43 \%)\end{array}$ & $\begin{array}{c}69(71 \%) \\
4(57 \%)\end{array}$ & $\begin{array}{c}97 \\
7\end{array}$ & $\begin{array}{c}1 \text { (ref) } \\
1.85(0.39-8.8)\end{array}$ & 0.4345 \\
\hline $\begin{array}{l}\text { IGHV, n (\%) } \\
\text { Mutated } \\
\text { Unmutated }\end{array}$ & $\begin{array}{l}19(40 \%) \\
27(32 \%)\end{array}$ & $\begin{array}{l}29(60 \%) \\
57(68 \%)\end{array}$ & $\begin{array}{l}48 \\
84\end{array}$ & $\begin{array}{c}1 \text { (ref) } \\
0.72(0.35-1.51)\end{array}$ & 0.3881 \\
\hline $\begin{array}{l}\text { WBC }\left(\times 10^{\%} / \mathrm{L}\right) \\
\leq 100 \times 10^{9} / \mathrm{L}, \mathrm{n}(\%) \\
>100 \times 10^{\circ} / \mathrm{L}, \mathrm{n}(\%)\end{array}$ & $\begin{array}{c}13.5 \\
154(44 \%) \\
6(24 \%)\end{array}$ & $\begin{array}{c}10.8 \\
194(56 \%) \\
19(76 \%)\end{array}$ & $\begin{array}{c}348 \\
25\end{array}$ & $\begin{array}{c}1 \text { (ref) } \\
0.4(0.16-1.02)\end{array}$ & $\begin{array}{l}0.086 \\
0.0481\end{array}$ \\
\hline $\begin{array}{l}\text { Hemoglobin, mg/dL } \\
\text { Normal, n (\%) } \\
\text { Low, n (\%) }\end{array}$ & $\begin{array}{c}13.6 \\
116(51 \%) \\
44(30 \%)\end{array}$ & $\begin{array}{c}13.055 \\
110(49 \%) \\
103(70 \%)\end{array}$ & $\begin{array}{l}226 \\
147\end{array}$ & $\begin{array}{c}1 \text { (ref) } \\
0.41(0.26-0.63)\end{array}$ & $\begin{array}{l}0.002 \\
<0.001\end{array}$ \\
\hline $\begin{array}{l}\text { Platelets, x10\%/L } \\
\text { Normal, n (\%) } \\
\text { Low, n (\%) }\end{array}$ & $\begin{array}{c}179 \\
104(51 \%) \\
53(33 \%)\end{array}$ & $\begin{array}{c}145 \\
101(49 \%) \\
110(67 \%)\end{array}$ & $\begin{array}{l}205 \\
163\end{array}$ & $\begin{array}{c}1 \text { (ref) } \\
0.47(0.31-0.72)\end{array}$ & $\begin{array}{l}<0.001 \\
0.0004\end{array}$ \\
\hline $\begin{array}{l}\text { ANC, } x 10^{9} / \mathrm{L} \\
\geq 1,500 \\
<1,500\end{array}$ & $\begin{array}{c}3.8 \\
119(43 \%) \\
32(41 \%)\end{array}$ & $\begin{array}{c}3.355 \\
156(57 \%) \\
47(59 \%)\end{array}$ & $\begin{array}{c}275 \\
79\end{array}$ & $\begin{array}{c}1 \text { (ref) } \\
0.89(0.54-1.48)\end{array}$ & $\begin{array}{l}0.754 \\
0.6613\end{array}$ \\
\hline $\begin{array}{l}\text { IgG, mg/dL } \\
\geq 700 \mathrm{mg} / \mathrm{dL}, \mathrm{n}(\%) \\
<700 \mathrm{mg} / \mathrm{dL}, \mathrm{n}(\%)\end{array}$ & $\begin{array}{c}844 \\
88(47 \%) \\
37(28 \%)\end{array}$ & $\begin{array}{c}709 \\
99(53 \%) \\
93(72 \%)\end{array}$ & $\begin{array}{l}187 \\
130\end{array}$ & $\begin{array}{c}1 \text { (ref) } \\
0.45(0.28-0.72)\end{array}$ & $\begin{array}{l}0.001 \\
<0.001\end{array}$ \\
\hline $\begin{array}{l}\text { IgM, mg/dL } \\
\geq 40 \mathrm{mg} / \mathrm{dL}, \mathrm{n}(\%) \\
<40 \mathrm{mg} / \mathrm{dL}, \mathrm{n}(\%)\end{array}$ & $\begin{array}{c}46.8 \\
76(57 \%) \\
43(26 \%)\end{array}$ & $\begin{array}{c}24.7 \\
58(43 \%) \\
123(74 \%)\end{array}$ & $\begin{array}{l}134 \\
166\end{array}$ & $\begin{array}{c}1 \text { (ref) } \\
0.27(0.16-0.43)\end{array}$ & $\begin{array}{l}<0.001 \\
<10-5\end{array}$ \\
\hline $\begin{array}{l}\text { IgA, mg/dL } \\
\quad \geq 80 \mathrm{mg} / \mathrm{dL}, \mathrm{n}(\%) \\
<80 \mathrm{mg} / \mathrm{dL}, \mathrm{n}(\%)\end{array}$ & $\begin{array}{c}109 \\
81(51 \%) \\
42(29 \%)\end{array}$ & $\begin{array}{c}65 \\
78(49 \%) \\
105(71 \%)\end{array}$ & $\begin{array}{l}159 \\
147\end{array}$ & $\begin{array}{c}1 \text { (ref) } \\
0.39(0.24-0.62)\end{array}$ & $\begin{array}{l}<0.001 \\
<0.001\end{array}$ \\
\hline $\begin{array}{l}\text { Monoclonal protein, } \\
\text { No } \\
\text { Yes }\end{array}$ & $\begin{array}{l}67(45 \%) \\
10(45 \%)\end{array}$ & $\begin{array}{l}83(55 \%) \\
12(55 \%)\end{array}$ & $\begin{array}{l}150 \\
22\end{array}$ & $\begin{array}{c}1 \text { (ref) } \\
1.03(0.42-2.54)\end{array}$ & 0.9447 \\
\hline
\end{tabular}

95\% CI: 95\% confidence interval, del: deletion;WBC: white blood cell count; ANC: absolute neutrophil count.

Contrariwise, an ineffective response was more frequently seen in older patients (not as reported in the healthy population $^{2}$ ) who had received several lines of prior therapies.

We also report the negative effect of ongoing therapy with novel anti-CLL agents on the immune response to the vaccine. In our cohort there were 79 and 34 patients receiving ongoing therapy with BTK inhibitors and BCL2 inhibitors, respectively, and less than $20 \%$ of them had a response to the vaccine. In addition, our findings also support the observations recorded by others in earlier studies regarding the development of B-cell depletion and late Bcell reconstitution following anti-CD20 antibody treatment..$^{15}$ In our cohort we noted in particular that patients who had been treated with anti-CD20 antibodies in the 12 months preceding vaccination had a clearly much lower response and only $5 \%$ responded effectively to the vaccine. Recently, Herishanu et al. ${ }^{16}$ reported that the humoral immune response to BNT162b2 mRNA COVID-19 vaccine in 167 patients with CLL from a single center was 39.5\%. Similar to our results, response to the vaccine was markedly impaired and was affected by prior treatment status and the type of therapy given.

Our study documents real-world experience in a large cohort of patients and, for the first time, also examined neutralizing antibodies following vaccination in patients with CLL. This is important because, as recently reported by Garcia-Beltran et al., SARS-CoV-2 neutralizing antibodies predict the severity of COVID-19 and survival. ${ }^{22}$

While the results reported here are mostly in accordance with previously published observations, ${ }^{21}$ in our 
cohort neither gender nor IGHV mutation status was a statistically significant factor for positive response. In addition, by examining the correlation of complete blood count results with response rate, we found that both abnormal hemoglobin and platelet levels were associated with a low response rate.

During the course of the study and in the 3-month observation period after the second dose of vaccine only three out of 400 vaccinated patients developed COVID19 infection. One patient acquired the infection between the first dose and the second dose ( 3 weeks) and two patients 14 days and 24 days after the second dose. All three of them recovered uneventfully.

Several studies have indicated that not only does the tumor response play a role in the immune response after vaccination with BNT162b2 mRNA COVID-19 vaccine, but that other factors are also involved. Recent research showed that two doses of $1 \mu \mathrm{g}$ or $50 \mu \mathrm{g}$ of BNT162b1 can
Table 4. Multivariate analysis of serological response in patients with chronic lymphocytic leukemia.

\begin{tabular}{lccc} 
Variable & Odds ratio & $95 \% \mathrm{CI}$ & P-value \\
Age $>70$ years & 0.6543 & $(0.4323-0.9867)$ & 0.0444 \\
Male & 0.9315 & $(0.6138-1.4131)$ & 0.7385 \\
\hline CIRS score $\geq 6$ & 1.0697 & $(0.3281-3.533)$ & 0.9104 \\
Prior therapy $1^{\text {st }}$ line & 0.3013 & $(0.0208-3.0227)$ & 0.3243 \\
\hline Prior therapy $\geq 2^{\text {nd }}$ line & 0.1246 & $(0.0082-1.2373)$ & 0.0891 \\
Time since last anti- & & & \\
CD20 antibodies $\leq 12$ months & 0.0874 & $(0.0046-0.5103)$ & 0.0256 \\
\hline IgG $<700 \mathrm{mg} / \mathrm{dL}$ & 0.7358 & $(0.4199-1.2906)$ & 0.0012 \\
IgM $<40 \mathrm{mg} / \mathrm{dL}$ & 0.3944 & $(0.2379-0.6493)$ & $<.001$ \\
\hline IgA $<80 \mathrm{mg} / \mathrm{dL}$ & 0.6052 & $(0.3555-1.0278)$ & 0.0631 \\
Ongoing BTK inhibitor & 0.0577 & $(0.0069-0.3195)$ & 0.0029 \\
\hline Ongoing BCL2 inhibitor & 0.1516 & $(0.005-2.22)$ & 0.1989 \\
\hline
\end{tabular}

95\% CI: $95 \%$ confidence interval; CIRS: Cumulative Illness Rating Scale.

Vaccine response rate by treatment status

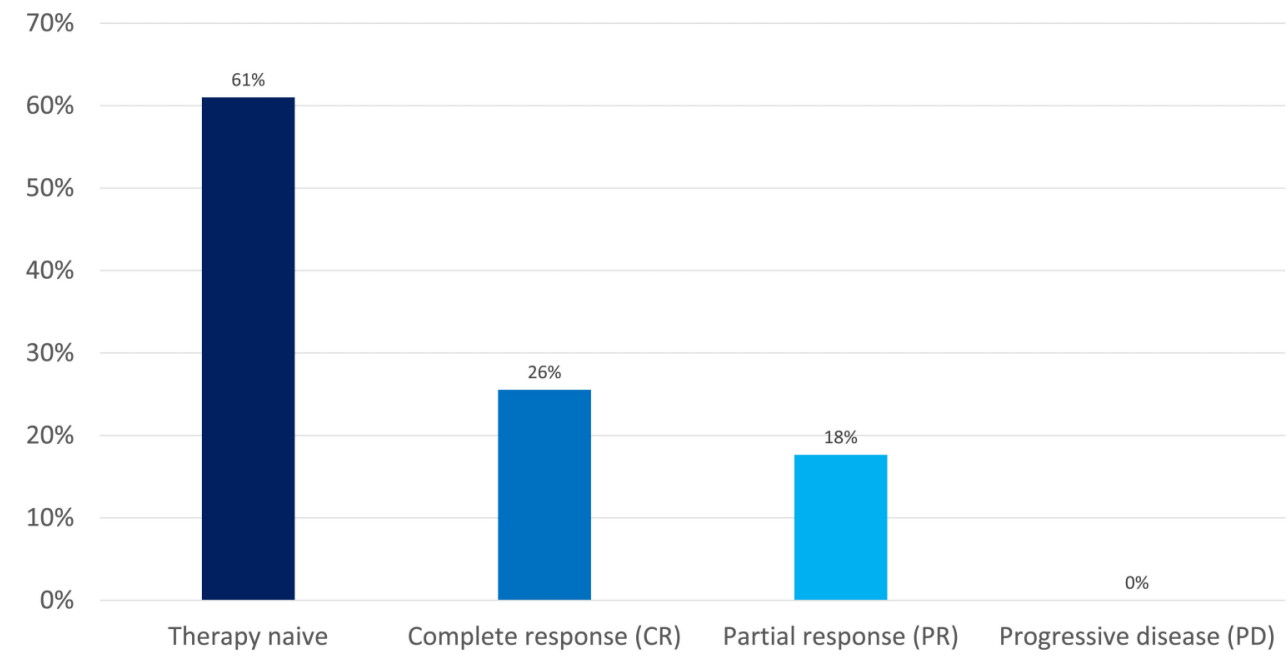

Vaccine response rate by treatment

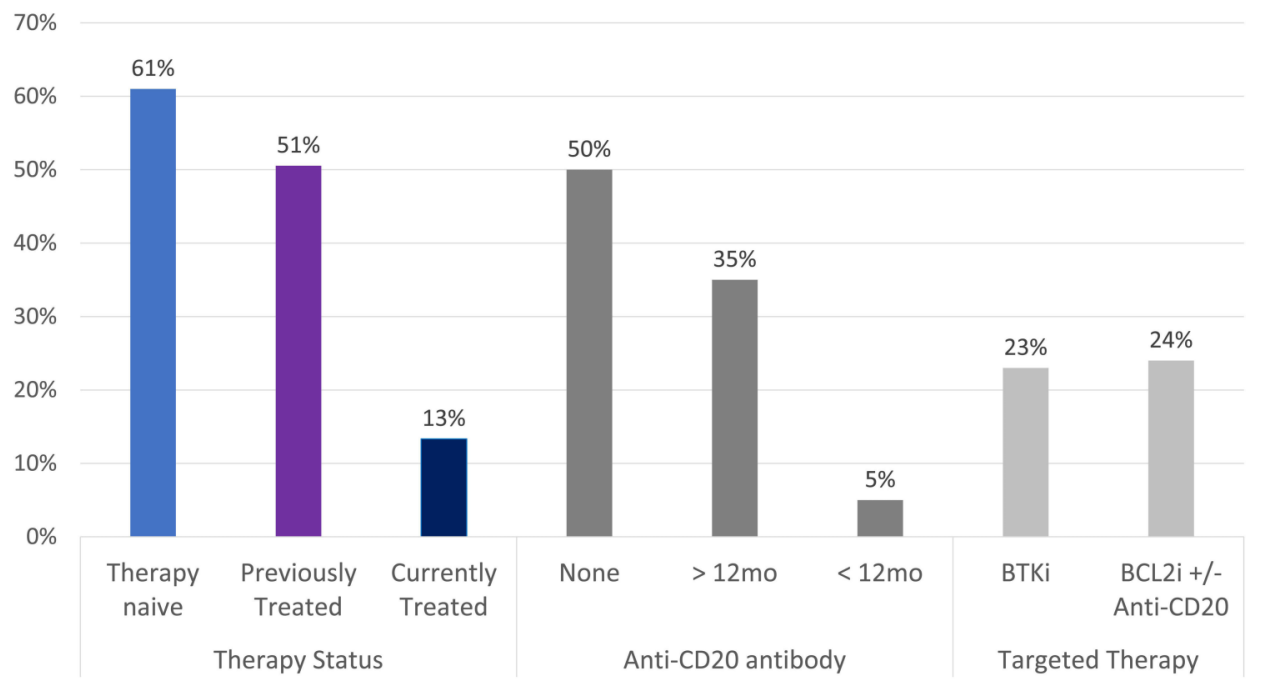

Figure 3. Vaccine efficacy according to treatment. Vaccine response rate by treatment status, by treatment type and treatment timing and response to vaccine in patients who were treated or are currently being treated with BKT inhibitors or BCL2 inhibitors. mo: months; BKTi: BKT inhibitor; BCL2i: BCL2 inhibitor. 
Scoring Model and Response Rate

\begin{tabular}{|c|c|c|c|c|c|}
\hline $80 \%$ & & & $75 \%$ & & \\
\hline \multirow[t]{2}{*}{$70 \%$} & & & & Factor & Score \\
\hline & & & & No anti-CD20 in the last year & 30 \\
\hline $60 \%$ & & & & Therapy naive & 10 \\
\hline $50 \%$ & & & & Age $<70$ & 10 \\
\hline $40 \%$ & & $36 \%$ & & Normal IgM (>=40) & 10 \\
\hline \multirow{2}{*}{$30 \%$} & & & & Normal IgA $(>=80)$ & 10 \\
\hline & & & & Normal IgG (>=700) & 10 \\
\hline $10 \%$ & $5 \%$ & & & $\begin{array}{l}\text { Normal Hgb ( }>=13.5 \mathrm{~g} / \mathrm{dL} \text { for males } \\
\text { OR }>=12 \mathrm{~g} / \mathrm{dL} \text { for females }\end{array}$ & 10 \\
\hline \multirow[t]{2}{*}{$0 \%$} & & & & Total & 90 \\
\hline & Low $(<20)$ & Intermediate (20-70) & High $(>70)$ & & \\
\hline
\end{tabular}

Figure 4. A simple scoring model to predict response to the BNT162b2 mRNA COVID-19 vaccine in individual patients with chronic lymphocytic leukemia. IgM, IgA and lgM levels in $\mathrm{mg} / \mathrm{dL} ;$ Hgb: hemoglobin.

elicit robust $\mathrm{CD}^{+}$and $\mathrm{CD}^{+}{ }^{+} \mathrm{T}$-cell responses. ${ }^{23}$ More data regarding the role of cellular responses in patients with CLL are still awaited in order to establish whether this system provides additional protection or whether the Tcell anergy known to occur in these patients also affects this particular arm of the immune response. However, based on our understanding of immunity to virus vaccinations, T-cell immunity has a major role in generating durable immunity. In addition, as detailed in the varicella-zoster vaccine study referenced above, ${ }^{12}$ CLL patients can generate potentially effective antigen-specific $\mathrm{CD}^{+}$ $\mathrm{T}$-cell responses to vaccines even when on treatment with BTK inhibitors.

In principle, it seems to be important to be able to predict the response to vaccination in patients with CLL and because of this we have formulated an original, simple, seven-parameter score which can be readily applied worldwide. It should, however, be taken into consideration that we based our model on in vitro markers of humoral immunity that do not necessarily predict clinical benefit and it should, therefore, be used with caution.

Our study has several limitations: Firstly, we used three different assays to measure immune response in our cohort of patients and differences between these commercial kits and their reference ranges must be taken into consideration. On the other hand, the results obtained appear to reflect the true "real-world" situation accurately, in which several different kits are being used worldwide with all achieving similar results. Indeed, a study comparing the sensitivity of the various serological assays has already been published indicating a sensitivity of $84.7 \%, 82.4 \%$ and $89.4 \%$ for the Abbott, DiaSorin and ELISA kits, respectively. ${ }^{17,18}$ Other research has also shown strong agreement between the results of different kits. ${ }^{16}$ A second limitation of our study is that it lacks data regarding possible past exposure or asymptomatic illness to SARS-CoV-2 itself. because the "local policy" was to vaccinate only the "non-infected/recovering from COVID-19 infection" population. We feel that this decision could possibly have affected our results but only in a very limited manner.

In conclusion, the results of this study showed that the humoral immune response to the BNT162b2 mRNA COVID-19 vaccine is impaired in patients with CLL. We were able to generate a simple seven-parameter score which helps to predict individual immune responses. Further studies are still required to define the exact role of the cellular immune response and the possible effect of a third dose of the vaccine in these patients.

In the long run it is our responsibility as a society to ensure that a high percentage of the healthy population is vaccinated so that we can protect more vulnerable individuals with underlying disorders such as CLL who are only partially capable of mounting an effective immune response following vaccination.

\section{Disclosures}

No conflicts of interest to disclose.

\section{Contributions}

$T T$ and $O B$ designed, organized and wrote the manuscript. LR performed the statistical and machine learning analysis including the seven-parameter models, and was involved in writing the manuscript. APol helped to write the manuscript. GI, AB, LS, NG, SS, $N D, A A, G R Y L, S S B D, R F, A P a z$, and IL contributed patients data.

\section{Acknowledgments}

We thank the study coordinators, with special thanks to Mrs. Andrea Shoukair.

\section{Funding}

This study was supported by a grant from Janssen Pharmaceutical, number EV00261620. 


\section{References}

1.Zhu N, Zhang D, Wang W, et al. A novel coronavirus from patients with pneumonia in China, 2019. N Engl J Med. 2020;382(8): 727-733.

2. Polack FP, Thomas SI, Kitchin N, et al. Safety and efficacy of the BNT162b2 mRNA Covid-19 vaccine. N Engl J Med. 2020;383(27):2 603-2615

3. https://www.fda.gov/emergency-preparedness-and-response/coronavirus-disease-2019-covid-19/pfizer-biontech-covid19-vaccine [last accessed May 19, 2021]

4. Dagan N, Barda N, Kepten E, et al. BNT162b2 mRNA Covid-19 vaccine in a nationwide mass vaccination setting. N Engl J Med. 2021;384(15):1412-1423.

5. Tadmor T, Welslau M, Hus I. A review of the infection pathogenesis and prophylaxis recommendations in patients with chronic lymphocytic leukemia. Expert Rev Hematol. 2018;11(1):57-70.

6. Hallek M, Cheson BD, Catovsky D, et al. iwCLL guidelines for diagnosis, indications for treatment, response assessment, and supportive management of CLL. Blood. 2018;131(25):2745-2760

7. Scarfo L, Chatzikonstantinou T, Rigolin GM, et al. COVID-19 severity and mortality in patients with chronic lymphocytic leukemia: a joint study by ERIC, the European Research Initiative on CLL, and CLL Campus. Leukemia. 2020;34(9):23542363.

8. Furstenau M, Langerbeins P, De Silva N, et al. COVID-19 among fit patients with CLL treated with venetoclax-based combina- tions. Leukemia. 2020;34(8):2225-2229.

9. Mato AR, Roeker LE, Lamanna N, et al. Outcomes of COVID-19 in patients with CLL: a multicenter international experience. Blood. 2020;136(10):1134-1143.

10. Whitaker JA, Parikh SA, Shanafelt TD, et al. The humoral immune response to highdose influenza vaccine in persons with monoclonal B-cell lymphocytosis (MBL) and chronic lymphocytic leukemia (CLL). Vaccine. 2021;39(7):1122-1130.

11. Svensson T, Kattstrom M, Hammarlund $Y$, et al. Pneumococcal conjugate vaccine triggers a better immune response than pneumococcal polysaccharide vaccine in patients with chronic lymphocytic leukemia. A randomized study by the Swedish CLL group. Vaccine. 2018;36(25): 3701-3707.

12. Zent CS, Brady MT, Delage C, et al. Short term results of vaccination with adjuvanted recombinant varicella zoster glycoprotein E during initial BTK inhibitor therapy for CLL or lymphoplasmacytic lymphoma. Leukemia. 2021;35(6):1788-1791.

13. Pleyer C, Ali MA, Cohen JI, et al. Effect of Bruton tyrosine kinase inhibitor on efficacy of adjuvanted recombinant hepatitis $B$ and zoster vaccines. Blood. 2021;137(2):185189.

14. Shadman M, Ujjani C. Vaccinations in CLL: implications for COVID-19. Blood. 2021;137(2):144-146.

15. Eisenberg RA, Jawad AF, Boyer J, et al. Rituximab-treated patients have a poor response to influenza vaccination. J Clin Immunol. 2013;(33):388-396

16. Herishanu Y, Avivi A, Aharon A, et al.
Efficacy of the BNT162b2 mRNA COVID19 vaccine in patients with chronic lymphocytic leukemia. Blood. 2021;137(23): 3165-3173.

17. Oved K, Olmer L, Shemer-Avni Y, et al. Multi-center nationwide comparison of seven serology assays reveals a SARS-CoV2 non-responding seronegative subpopulation. EClinicalMedicine. 2020;29;100651.

18. Perkmann T, Perkmann-Nagele N, Breyer MK, et al. Side-by-side comparison of three fully automated SARS-CoV-2 antibody assays with a focus on specificity. Clin Chem. 2020;66(11):1405-1413.

19. Dieterle ME, Haslwanter D, Bortz RH 3rd, et al. A replication-competent vesicular stomatitis virus for studies of SARS-CoV-2 spike-mediated cell entry and its inhibition. Cell Host Microbe. 2020;28(3):486-496.

20. Ribbing J, Nyberg J, Caster O, Jonsson EN. The lasso - a novel method for predictive covariate model building in nonlinear mixed effects models. J Pharmacokinet Pharmacodyn. 2007;34(4):485-517.

21. Kim SM, Kim Y, Jeong K, Jeong H, Kim J. Logistic LASSO regression for the diagnosis of breast cancer using clinical demographic data and the BI-RADS lexicon for ultrasonography. Ultrasonoography. 2018;37 (1):36-42.

22. Garcia-Beltran WF, Lam EC, Astudillo MG, et al. COVID-19-neutralizing antibodies predict disease severity and survival. Cell. 2021;184(2):476-488

23. Sahin U, Muik A, Derhovanessian E, et al. COVID-19 vaccine BNT162b1 elicits human antibody and TH1 T cell responses. Nature. 2020;586(7830):594-599. 